\title{
Responsabilidade civil do médico-cirurgião plástico e seus reflexos processuais ${ }^{1}$ \\ Liability of Medical plastic surgeon and its procedural reflections
}

\author{
Diego Prado da Silveira ${ }^{2}$ \\ Wagner Vinicius de Oliveira ${ }^{3}$
}

\begin{abstract}
Resumo
O presente artigo examina a responsabilidade civil médica nas cirurgias plásticas estéticas, tendo em vista a divergência quanto a sua natureza jurídica: se obrigação de meio ou de resultado. Com o objetivo de construir esclarecimentos acerca da obrigação de meio (posicionamento ao qual se filia), especialmente quanto ao ônus probatório e os seus reflexos na responsabilização civil médica, analisou-se as formas de dano que poderão decorrer do ato cirúrgico; a promessa, expressa e inequívoca, realizada ao paciente, conditio sine qua non, para ensejar obrigação de resultado; as condições pessoais que podem impedir o alcance do resultado; os entendimentos jurisprudenciais que corroboram o posicionamento acima afirmado, bem como a aplicabilidade do Código de Defesa do Consumidor nas relações médico e paciente. Por fim, afirma-se que o médico-cirurgião plástico possuí, em regra, obrigação de meio; exatamente por haver firme conexão do negócio jurídico com a realidade fática de modo a consubstanciar as razões que conduzem a essa classificação.
\end{abstract}

Palavras-chaves: Obrigação de meio. Obrigação de resultado. Promessa. Responsabilidade civil médica.

\begin{abstract}
This article examines the medical liability in aesthetic plastic surgery, with a view to divergence as its legal status is obligation of means or of result. In order to build clarifications on medium duty (position which is affiliated), especially as the evidential burden and its effects on medical, civil liability analyzed forms of damage which may result from the surgery; the promise, expressly and unequivocally, held to the patient, conditio sine qua non, to give rise obligation of result; personal circumstances that may impede the achievement of results; the jurisprudential understandings that support the position stated above as well as the applicability of the Consumer Protection Code in physician and patient relations. Finally, it is stated that the plastic surgeon doctor-owned, as a rule, through obligation; exactly for having strong legal business connection with the factual reality in order to substantiate the reasons leading to this classification.
\end{abstract}

Keywords: Obligation of means. Obligation of results. Promisse. Medical liability.

Artigo recebido em 15 de maio de 2015 e aprovado em 15 de fevereiro de 2016.

${ }^{1}$ Artigo desenvolvido a partir da pesquisa financiada pelo Programa de Bolsas de Iniciação Científica PROBIC - Pontifícia Universidade Católica de Minas Gerais - PUC Minas - Pró-reitoria de Pesquisa e de Pós-graduação - PROPPG, sob orientação do Prof. Dr. Luiz Augusto Lima de Ávila, em 2014.

${ }^{2}$ Graduando no curso de Direito pela Pontifícia Universidade Católica de Minas Gerais - PUC Minas Barreiro. E-mail: diego.prado@sga.pucminas.br

${ }^{3}$ Graduando no curso de Direito pela Pontifícia Universidade Católica de Minas Gerais - PUC Minas Barreiro. E-mail: wagner.vinicius@sga.pucminas.br 


\section{Introdução}

A responsabilidade civil médica é questão que fomenta o debate, principalmente na atuação do médico-cirurgião plástico, ainda mais quando considerado o crescente número de cirurgias plásticas realizadas. Com a elevada demanda judicial de pacientes insatisfeitos com os resultados obtidos na intervenção cirúrgica, postulando, de algum modo, reparar à frustração da expectativa gerada e não correspondida, os médicos, com frequência, têm figurado no polo passivo de demandas indenizatórias. Certamente, o médico não deseja errar, contudo, falhas poderão ocorrer, afinal, errare humanum est, não podendo exigirlhes a infalibilidade.

Em face dessas considerações preliminares o presente artigo investiga a responsabilidade civil médica nas cirurgias plásticas estéticas, analisando o tema sob uma perspectiva que se distancia do lugar comum. A partir da premissa de que o médico cirurgião plástico possuí, em regra, obrigação de meio o artigo pretende dissidiar-se do entendimento majoritário.

Para tanto, num primeiro momento, procurou-se traçar os contornos da relação obrigacional médica em ambas as modalidades de obrigação. Ressaltando, que diferente dos demais procedimentos médicos, o entendimento majoritário é que a cirurgia plástica é considerada como obrigação de resultado. Não bastando, portanto, que tenham sido usadas a melhores técnicas durante os procedimentos, já que o intuito é entregar ao paciente o resultado esperado.

A distinção das referidas obrigações é colocada em evidência com base em entendimentos jurisprudenciais e na promessa realizada pelo esculápio ao paciente, por exercer papel fundamental quanto ao adimplemento obrigacional, especialmente, no tocante ao ônus probatório e sua compreensão no contexto processual. Imprescindível analisar o conceito de ambas as obrigações, bem como as implicações quanto a responsabilização civil.

Insta acrescentar que o médico não está jungido a realizar o improvável. Para compreensão do tema é fundamental o entendimento dessa questão frente a relação obrigacional entre médico e paciente na cirurgia plástica estética.

Em um segundo momento, analisou-se os eventuais danos que podem originar da cirurgia plástica e o seu tratamento jurídico realizado pelo Código de Defesa do Consumidor - CDC. Tendo em vista que a responsabilidade civil, possui correspondência 
com a contraprestação, demonstrada etimologicamente, pela expressão latina respondere, conduzindo à ideia de segurança, garantia etc.

Por fim, demostrou-se, de modo sintético, as repercussões advindas da classificação da atividade do médico-cirurgião plástico como obrigação de meio, notadamente com seus reflexos na fase instrutória em um procedimento judicial de indenização por perdas e danos, tendo como causa de pedir a reparação/compensação dos danos advindos de uma cirurgia plástica estética.

Em última análise, objetivo desse artigo é a segurança jurídica, para fins de se estender os cuidados médicos à saúde dos pacientes, pois, o senso comum influenciado por diversos motivos, confunde o imponderável direito à segurança com a "cura" ou "embelezamento".

Espera-se, em decorrência do exposto, o reconhecimento do Princípio da Dignidade da Pessoa Humana, vetor axiológico interpretativo de todo o Ordenamento Jurídico, com incidência nessas situações produzindo efeitos de verdadeira mudança paradigmática, pela releitura da atividade médica, interpretada, em regra, como obrigação de meio.

\section{Relação obrigacional médica}

A problemática abrolha quanto à questão da natureza jurídica da obrigação médica, que se encontra controversa, ressoando de forma não uníssona, haja vista, opiniões antagônicas em relação à classificação da obrigação assumida pelos cirurgiões plásticos, se de meio ou resultado.

Por haver divergência doutrinária quanto à natureza jurídica da obrigação do médico-cirurgião plástico surge, então, a celeuma: essa modalidade de obrigação deve ser considerada de meio ou de resultado?

\subsection{Obrigação de resultado}

As intervenções médicas, em regra, são consideradas, sob o enfoque jurídico, como obrigação de meio, nas quais o médico se compromete a utilizar de todas as técnicas possíveis para realizar a intervenção, visando um fim, porém não permanece adstrito ao mesmo. 
Válida para a quase totalidade das intervenções médicas, exceto nas cirurgias plásticas estéticas, com a (frágil) argumentação de que o paciente não possuía patologia, este raciocínio é acolhido por Carlos Roberto Gonçalves:

\footnotetext{
Quanto aos cirurgiões plásticos, a situação é outra. A obrigação que assumem é de resultado. Os pacientes, na maioria dos casos de cirurgia estética, não se encontram doentes, mas pretendem corrigir um defeito, um problema estético. Interessa - lhes, precipuamente, o resultado. (GONÇALVES, 2012, p. 263).
}

As obrigações de resultado são aquelas em que o contratado se obriga a obter um fim pretendido, sem o qual não se considera realizada a avença, por exemplo, o contrato de transporte ou empreitada. O resultado específico é a essência do contrato e, não o atingindo, não se adimpliu a obrigação, inexistindo espaço para a incerteza.

Utilizando, propositadamente, os mesmos termos ditos quando da exposição quanto a obrigação de meio - o contratado utiliza o máximo de esforço, diligência, dedicação, perícia etc., em não atingindo o resultado, não terá satisfeito a obrigação. Novamente recorre-se à dicção de Carlos Gonçalves: "Se o cliente fica com aspecto pior, após a cirurgia, não se alcançando o resultado que constituía a própria razão de ser do contrato, cabe-lhes o direito à pretensão indenizatória”. (GONÇALVES, 2012, p. 264).

Para que a obrigação de resultado tenha extinção normal, há a necessidade imperiosa de seu cumprimento a contento. Ao não atingir o resultado é considerado inadimplemento da obrigação e resulta em não receber a retribuição pecuniária e até mesmo ao contrário, obrigação de indenizar ao contratante. Exceções impostas por caso fortuito e força maior, devidamente comprovadas, são possíveis de excluírem a responsabilidade civil do contratado.

Presente o compromisso do contratado com um resultado específico, que é o cerne da própria obrigação, o contratado compromete-se a atingir o objetivo determinado, de sorte que, quando o fim almejado não for satisfeito, ou alcançado parcialmente, tem-se a inexecução da obrigação. Nas obrigações de resultado ocorre a presunção da culpa, com inversão do ônus da prova, cabendo ao réu provar em sede de defesa, o reverso do que lhe é imputado.

Considerando a cirurgia estética como obrigação de resultado, é fundamental a precisa distinção entre a cirurgia plástica estética e reparadora. Aquela possui seu objetivo limitado ao resultado puramente estético, visando aperfeiçoar o aspecto externo de parcela do corpo, nesta o paciente busca o cirurgião sem apresentar qualquer patologia, visa, apenas, o "puro embelezamento". 
Na cirurgia plástica reparadora ou reconstrutiva, a intervenção cirúrgica, ainda que promova melhoria estética, não tem neste seu objetivo principal. Pretende-se resolver problemas de outra natureza, como a correção de defeitos congênitos ou traumas decorrentes de acidentes, queimaduras etc. Segundo Paulo Nader:

\begin{abstract}
Para definição da responsabilidade médica, alguns autores distinguem as modalidades de cirurgia plástica. Se de natureza estética, a obrigação do profissional seria de resultado; se de natureza reparadora, de meio. Em princípio tal orientação é válida; todavia, o insucesso nas intervenções pode provocar efeitos jurídicos opostos. Há casos na cirurgia estética em que os resultados esperados não são alcançados por motivos alheios ao profissional, como por exemplo, a não observância pelo paciente das recomendações médicas no pós operatório. Em contrapartida, o médico pode ser responsabilizado por uma cirurgia reparadora, constatando-se que o dano causado foi por sua própria imperícia, imprudência ou negligência. (NADER, 2010, p. 411)
\end{abstract}

Parcela expressiva da doutrina brasileira opta pela classificação da cirurgia estética como obrigação de resultado. Baseando-se no fato de que o paciente não sendo portador de qualquer moléstia, mas desejando "melhorar" seu aspecto físico, pode-se afirmar que o seu objetivo é tão somente o resultado.

Neste sentido, preleciona Sílvio de Salvo Venosa (2010, p. 157): "Não se tratando de cirurgia estético-embelezadora ou exames clínicos, radiológicos e assemelhados, a obrigação médica é de meio. Não pode o médico assegurar a cura, o resultado".

Faz-se aqui uma ressalva: apenas a promessa, expressa e inequívoca, realizada ao paciente representa condição suficiente para ensejar obrigação de resultado. Comumente o tema promessa nas relações médico/paciente transcorre sem aprofundamentos, entretanto, entende-se que o tema necessita de elucidações adicionais, fornecidas por distintas áreas do conhecimento.

Pelo viés filosófico, Immanuel Kant analisa o aspecto moral da promessa:

Ponhamos por exemplo, a questão seguinte: - não posso eu quando me encontro em apuro, fazer uma promessa com a intenção de a não cumprir? Facilmente distingo aqui os dois sentidos que a questão pode ter: - se é prudente, ou se é conforme ao dever, fazer uma falsa promessa. O primeiro caso pode sem dúvida apresentar-se muitas vezes. É verdade que vejo bem que não basta furtar-me ao embaraço presente por meio desta escapatória, mas que tenho de ponderar se desta mentira me não poderão advir posteriormente incómodo maiores do que aqueles de que agora me liberto: e como as consequências, a despeito da minha pretensa esperteza, não são assim tão fáceis de prever, devo pensar que a confiança uma vez perdida me pode vir a ser mais prejudicial do que todo o mal que agora quero evitar; posso assim perguntar se não seria mais prudente agir em conformidade com uma máxima universal e adquirir o costume de não prometer nada senão com a intenção de cumprir a promessa. (KANT, 2000, p. 33-34, grifos no original). 
Assim como na filosofia moral, pode-se extrair elementos fundamentais à promessa médica, em especial, a conformidade com o dever, veracidade da promessa e prudência ao realizar o ato, são alguns dos parâmetros válidos para balizar o ato. De outra arte, tem-se de igual relevância, para o paciente a quem a promessa é dirigida, a convenção feita entre os indivíduos deve estar lúcida e em igual medida para as partes. Não restando margem para dúvidas ou dificuldades para o diálogo findar-se em consenso.

Para Kant (2000, p. 64), o conceito de dever é assim expressado: “[...] Pois o dever deve ser a necessidade prática-incondicionada da acção (sic); tem de valer para todos os seres racionais (os únicos aos quais se pode aplicar sempre um imperativo), e só por isso pode ser lei também para toda a vontade humana".

Avocando o imperativo da moralidade, que orienta não apenas sob o prisma ético, mas, também, sobre a relação obrigacional, não na perspectiva de mero aconselhamento (imperativo categórico), assevera o sobredito autor:

Não devemos fazer promessas enganadoras, - admitimos que a necessidade desta abstenção não é somente um conselho para evitar qualquer outro mal, como se disséssemos: Não deves fazer promessas mentirosas para não perderes o crédito quando se descobrir o teu procedimento; admitimos pelo contrário que uma aç̧ão (sic) desse género tem de ser considerada como má por si mesma, que o imperativo da proibição é, portanto, categórico [...]. (KANT, 2000, p. 56).

Apenas o probo dotado de credibilidade poderá fazer promessa, projeção de um estado de coisas no futuro dotado de força comissiva ou omissiva, com idoneidade de resposta àquela, em suma, o possuidor de confiança. Quando o esculápio ${ }^{4}$ prometer expressamente ao paciente determinado resultado vincula-se a este, pois desperta ou reforça o desejo do paciente, que deverá corresponder ao próprio resultado pretendido/prometido.

Além disso, convém ressaltar que as promessas são invenções humanas, fundadas nas necessidades e interesses sociais comuns, assim, são engajamentos entre pessoas, ou seja, são contratos. Considerando que o ato de comunicação expressa um estado psicológico, a promessa manifesta à intenção, porque antecede as convenções; possuí direção de ajuste mundo/palavra, condição de sinceridade e compromisso com a realização de ação futura como propósito firmado no presente ou no pretérito.

\footnotetext{
${ }^{4}$ Conforme o sítio eletrônico da Universidade Federal de Campina Grande: "Deus solar da saúde, que com o nome latinizado de Esculápio, era o deus romano da medicina e da cura".
} 
Com o auxílio da lógica formal pode-se entender melhor a natureza jurídica da relação obrigacional médica: se $\mathrm{A}$, então $\mathrm{B}(\mathrm{A} \rightarrow \mathrm{B})^{5}$, se prometer, então a obrigação será de resultado; se $\neg \mathrm{A}$, então $\mathrm{C}(\neg \mathrm{A} \rightarrow \mathrm{C})^{6}$, se não prometer, então será de meio, ausente à exigibilidade do resultado, ad argumentandum tantum, $\mathrm{B} \leftrightarrow \mathrm{A}^{7}$ (resultado se, e, somente se prometer). O resultado (B) deve ter como condicional o antecedente (A) promessa.

A proposição apodítica de que toda cirurgia plástica estética é de resultado é falaciosa (Todo A é B), como será demonstrado alhures, o mais adequado seria o modus (afirmativo ou negativo), algum A é B, ou ainda, algum A não é B. Assim, o raciocínio lógico para a cirurgia plástica estética deverá ser indutivo, partindo do particular para o geral, assim, as idiossincrasias poderão influir negativamente no resultado, devendo ser como nas demais cirurgias, obrigação de meio.

Corroborando acerca de eventos futuros contingentes, Luiz Augusto Lima de Ávila, afirma: “[...] mais precisamente, uma preposição P qualquer, correspondente a eventos futuros contingentes, não é verdadeira ou falsa antes do fato, senão que tão somente após o fato". (ÁVILA, 2013, p. 10).

O resultado (ou a expectativa) pode ser compreendido como um sofisma, ou seja, quando a conclusão das premissas deixa de ser apodítica e passa a ser provável. Afirma-se que a promessa (ato unilateral, livre e consciente) inequívoca e expressa é determinante para jungir o esculápio ao resultado, mesmo este sendo factível e de regularidade duvidosa.

A promessa é relevante para o Direito positivo; apenas para demonstrar sua importância na seara civil, o ato de prometer integra os negócios jurídicos, dentre outros, nos termos dos arts. $439^{8}, 466^{9}, 855^{10}$ e $1.417^{11}$ do Código Civil de 2002; da promessa de fato de terceiro, do contrato preliminar, promessa de recompensa e do direito do

\footnotetext{
5 Através do conectivo lógico, proposição condicional: "Se A, então B", possíveis outras expressões equivalentes, expressa uma condição suficiente para que determinado acontecimento ocorra.

6 Aplica-se raciocínio semelhante, porém, o símbolo ( $\neg)$, representa negação.

${ }^{7}$ Conectivo lógico bicondicional $(\leftrightarrow)$ : “A se, e, somente se B”.

${ }^{8}$ Lei n. 10.406/2002, Código Civil - CC, art. 439. Aquele que tiver prometido fato de terceiro responderá por perdas e danos, quando este o não executar.

${ }^{9}$ CC, art. 466. Se a promessa de contrato for unilateral, o credor, sob pena de ficar a mesma sem efeito, deverá manifestar-se no prazo nela previsto, ou, inexistindo este, no que lhe for razoavelmente assinado pelo devedor.

${ }^{10} \mathrm{CC}$, art. 855. Quem quer que, nos termos do artigo antecedente, fizer o serviço, ou satisfizer a condição, ainda que não pelo interesse da promessa, poderá exigir a recompensa estipulada.

${ }^{11} \mathrm{CC}$, art. 1.417. Mediante promessa de compra e venda, em que se não pactuou arrependimento, celebrada por instrumento público ou particular, e registrada no Cartório de Registro de Imóveis, adquire o promitente comprador direito real à aquisição do imóvel.
} 
promitente comprador, respectivamente, possuem o efeito da responsabilização civil précontratual, com fulcro na boa-fé objetiva.

As partes da relação obrigacional são: médico e paciente, em que está implícita a ideia de acordo de vontades convergentes; afinal, a Medicina existe para mitigar o sofrimento humano. Insuscetível confundir o objeto da obrigação contratual com a "cura" ou "embelezamento", mas, certamente a obligatio faciendi terá como objeto os serviços médicos nos limites da ciência contemporânea que contribuam para a "melhoria" do paciente.

Transmutar o "feio" em "belo", o "comum" em "extraordinário" ou o "vulgar" em "raridade" (caso estes adjetivos possam ser utilizados), é uma predicação da qual o médico definitivamente não possuí. Pela indisponibilidade natural relativa (contingência), em regra não poderão ser objetos da relação obrigacional, mas, de outra arte, tão somente os necessários serviços médicos.

$\mathrm{Na}$ fase de puntuação (tratativas) existe relação entre promessa e responsabilidade com implicações na esfera médica, vez que quando o esculápio promete (livre e consciente), determinado resultado vincula-se a ele. A promessa tem o condão de alterar a natureza jurídica da cirurgia médica, que em regra é considerada obrigação de meio passando a assumir a forma de obrigação de fim ou resultado.

Em atenção ao princípio da autonomia $\operatorname{privada}^{12}$, presente na modalidade de cirurgia plástica estética, pois a voluntariedade é preponderante para submeter-se ao procedimento médico.

Posterior à realização de minuciosos exames, caso o esculápio acreditar que conseguirá alcançar o resultado e expressamente jungir-se a ele, sendo as partes capazes e ausentes os vícios que maculam a vontade; aliás, sempre presente a prévia e exaustiva informação, desta forma, resulta incontroversa que a obrigação do esculápio será de resultado.

Destarte, o resultado prometido expressamente, integra a avença, de sorte que não o alcançando, caberá ao esculápio ressarcir ao paciente. Quando da ocorrência de vício na prestação dos serviços médicos decorrente de falha somente imputável a quem prometeu, afinal, pacta sunt servanda.

\footnotetext{
${ }^{12}$ Vale acrescentar, que o termo se refere a ultrapassada noção de autonomia da vontade, atualmente encontra-se limitada pela função social dos contratos.
} 
Nesse sentido, parece não haver divergência até mesmo entre os que se filiam a correntes doutrinárias opostas, refere-se a Stoco (2004, p. 533) “[...] Também há possibilidade da (sic) obrigação do médico ser de resultado quando assume expressamente a garantia da cura”. Acerca do tema, a concordância com o referido autor finda-se aqui.

Em convergência, Nestor J. Forster, advogado na cidade de Porto Alegre, afiança:

Evidentemente, não se focaliza aqui o cirurgião que assume o compromisso com o paciente de atingir determinado resultado. É claro que, se tal compromisso existir, ele responde por inteiro pelos resultados que discrepem daqueles buscados pelo paciente e prometidos pelo profissional. (FORSTER, 1997, p. 412).

Afirma-se que a tradição criou o hábito de nas cirurgias plásticas estéticas o médico sucumbir ao desejo do paciente e comprometer-se a determinado fim, com suposto resultado ainda mais determinado. Aqui obervamos que a hegemonia tradicionalista culminou em misoneísmo - aversão a transformações; apego a velhos hábitos etc.

Tem-se por igual monta que é importante o esclarecimento da real intenção das partes na celebração do negócio jurídico, visto que a disposição expressa no Código Civil de 2002 revela-se como paradigma quando dispõe nos termos do art. 112: "Nas declarações de vontade se atenderá mais à intenção nelas consubstanciada do que ao sentido literal da linguagem". (BRASIL, 2002).

Por haver tensão entre realismo e idealismo é que ao médico prudente recomendase dispensar especial atenção e assessoramento por profissional, devidamente habilitado(a), na área do Direito para construção do termo de consentimento, por instrumento particular escrito. Também deve haver a observação do disposto no Código de Ética Médica ${ }^{13}$, outrossim, o Código de Defesa do Consumidor ${ }^{14}$ - CDC (Lei n. 8.078/90), delimitando o negócio jurídico, deixando seus contornos demarcados.

Contudo, a cirurgia plástica é um ramo da cirurgia geral, estando sujeita aos mesmos imprevistos e insucessos daquela, de modo não ser possível punir mais

${ }^{13}$ É vedado ao médico:

Art. 22. Deixar de obter consentimento do paciente ou de seu representante legal após esclarecê-lo sobre o procedimento a ser realizado, salvo em caso de risco iminente de morte.

${ }^{14} \mathrm{CDC}$, Art. $6^{\circ}$ São direitos básicos do consumidor:

III - a informação adequada e clara sobre os diferentes produtos e serviços, com especificação correta de quantidade, características, composição, qualidade e preço, bem como sobre os riscos que apresentem;

Art. 31. A oferta e apresentação de produtos ou serviços devem assegurar informações corretas, claras, precisas, ostensivas e em língua portuguesa sobre suas características, qualidades, quantidade, composição, preço, garantia, prazos de validade e origem, entre outros dados, bem como sobre os riscos que apresentam à saúde e segurança dos consumidores. 
severamente o cirurgião plástico do que o cirurgião geral, haja vista submeterem-se à mesma álea.

\title{
1.3 Obrigação de meio
}

Segundo a Organização Mundial da Saúde - OMS: "saúde é um estado de completo bem-estar físico, mental e social, e não consiste apenas na ausência de doença ou de enfermidade" ${ }^{15}$ (ORGANIZAÇÃO MUNDIAL DA SAÚDE, 1946), em harmonia com os objetivos da cirurgia plástica, independentemente de sua espécie; estando, portanto, inserida no amplo conceito de saúde, que engloba o físico, psíquico e o moral.

Para compreensão do tema em profundidade é necessária uma guinada axiológica no discurso, devem-se considerar questões bioéticas e entender que a ciência médica é imperfeita, pois decorre das limitações do conhecimento científico, em constante aperfeiçoamento, devido também a variabilidade do resultado. Assim, é preciso analisar a relação médico/paciente exclusivamente sob o prisma jurídico.

A obrigação de meio encontra fundamento na Resolução n. 1.621/2001 do Conselho Federal de Medicina - CFM, em suas considerações preliminares, acertadamente põe a lume:

\footnotetext{
CONSIDERANDO que a diversidade de resposta biológica é inerente às características individuais e genéricas; [...]

CONSIDERANDO a necessidade de informar a Sociedade Civil e esclarecer dúvidas quanto à função da Cirurgia Plástica como especialidade médica; (CONSELHO FEDERAL DE MEDICINA, 2001, p. 01).
}

A partir de tais premissas, o resultado não deverá integrar a relação contratual, na qual o cirurgião plástico não será compelido a alcançá-lo, embora aquele seja a motivação. As limitações médicas (ciência) e biológicas (pessoais) são preponderantes ao animus dos contratantes estando, portanto, subjacente à realidade fática.

Diante de tais constatações, o CFM resolve:

\begin{abstract}
Art. $3^{\circ}$. Na Cirurgia Plástica, como em qualquer especialidade médica, não se pode prometer resultados ou garantir o sucesso do tratamento, devendo o médico informar ao paciente, de forma clara, os benefícios e riscos do procedimento.

Art. $4^{\circ}$. O objetivo do ato médico na Cirurgia Plástica como em toda a prática médica constitui obrigação de meio e não de fim ou resultado. (CONSELHO FEDERAL DE MEDICINA, 2001, p. 01).
\end{abstract}

\footnotetext{
${ }^{15}$ Constituição da Organização Mundial da Saúde - OMS/WHO - 1946.
} 
Não se olvida que o entendimento do CFM ratifica a Resolução n. 81/1997 do Conselho Regional de Medicina do Estado de São Paulo - CREMESP, em sentido idêntico, nos termos dos arts. $4^{\circ}$ e $5^{\circ}$, respectivamente.

Obrigação de meio é o comprometimento que o contratante faz com a outra parte de prestar serviços com o melhor de sua força física, intelectual e técnica; assim como, com a responsabilidade normal que se espera de um(a) profissional qualificado(a). Indica que há o comprometimento de dedicação pessoal com vistas ao melhor resultado, porém, sem a obrigação de consegui-lo.

A relação jurídica obrigacional é caracterizada pela formação de vínculo patrimonial, mediante o qual uma parte pode exigir da outra determinada prestação. Vale ressaltar o posicionamento de Arnaldo Rizzardo:

[...] se cristalizou uma tentativa de estabelecer a responsabilidade de meio para a cirurgia corretiva, e de resultado para a estética, sob o falho prisma de, nesta, se comprometer a exprimir na pessoa uma melhora no exterior do corpo, como se, nas demais cirurgias, não influa o intento de sanar imperfeições e dar aspecto mais agradável à aparência. (RIZZARDO, 2009, p. 345).

Em síntese, obrigação de meio é aquela na qual o contratado assume não o resultado certo e desejado, mas, compromete-se a exercê-la com diligência, esforço e dedicação; além da inteligência (técnica) em realizar a obrigação de fazer. Ao celebrarem o contrato, o médico compromete-se a aplicar todo conhecimento e dedicação possíveis para obter o melhor resultado. Porém, não se compromete em atingir o resultado pretendido pelo contratante. Rizzardo, assim preceitua:

Colocando-se frente à realidade, encontra-se uma conclusão irrefragável: em todas as cirurgias existem os mesmos riscos, a mesma álea, e impõem-se idênticos cuidados. Nem é possível esperar que todos os seres humanos reajam igualmente, ou tenham uma resistência forte às infecções, e cicatrizem em espaço de tempo curto. (RIZZARDO, 2009, p. 346).

O contrato impõe ao devedor a realização de certa atividade, com propósito determinado, mas sem compromisso de atingi-lo. O contratado obriga-se a realiza-lo com diligência, utilizando a técnica disponível, o resultado exigível do cirurgião plástico é que seja individual e socialmente adequado.

Quando o paciente procura o(a) médico(a), o faz porque sente sua saúde debilitada ou por prevenção (check-up). Existe a tentativa de estabelecer a obrigação de meio apenas para as cirurgias plásticas reparadoras, considerando a hipótese de que na cirurgia estética 
o paciente não apresentar patologia alguma, assim, supostamente, será obrigação de resultado.

Em oposição, a discente (à época) Fabiana Tsukamoto, em sua monografia, coerentemente, assevera:

Para refutar os argumentos de que um paciente que recorre à cirurgia plástica estética, a fim de melhorar sua forma física, está bem de saúde e que, portanto, o médico estaria obrigado pelo resultado, tem-se defendido que esta pessoa pode estar psicologicamente alterada em consequência de imperfeições. Neste caso, a cirurgia se prestaria a devolver a normalidade psíquica e física ao paciente. Isto porque não há elementos objetivos que possibilitem precisar com exatidão os limites da cirurgia estética e da cirurgia reparadora. (TSUKAMOTO, 2004, p. $50)$.

Reconhecer as cirurgias plásticas estéticas como obrigação de resultado é desconsiderar todas as peculiaridades de reação do organismo humano, que reage de modo diverso as agressões do ato cirúrgico. Em idêntico sentido aduz, Arnaldo Rizzardo:

\footnotetext{
Nunca se pode olvidar que cada ser humano é diferente, com sua genética, o seu passado, trazendo carga de influências desde o ventre materno, e repercutindo no futuro os choques e as mazelas da primeira infância, e mesmo os impactos da vida intra-uterina. (RIZZARDO, 2009, p. 346).
}

Ao realizar uma cirurgia, o médico possuí o compromisso de dedicar-se, com a maior competência possível, mas não pode garantir, com certeza, o resultado. Na obrigação de meio, o objeto contratual é a própria atividade médica.

Havendo insatisfação com o resultado alcançado, sendo um contrato obrigacional de meio, o que se analisa é se o médico atuou com o profissionalismo possível, aplicando os recursos possíveis na consecução do resultado, dentro dos limites da técnica atual, ponderando fatores genéticos de cada paciente. Novamente recorre-se à dicção de Rizzardo (2009, p. 346): "Não se equipara o organismo humano a uma máquina submetida às leis da física e da mecânica, ou que obedece a mecanismos estanques e idênticos de cura, de cicatrização, de imunidade a agentes externos".

Comprovada a utilização dos métodos possíveis pelo(a) profissional, no contrato de meio, ainda que o fim não tenha sido alcançado, não há como falar-se em indenização pelo não cumprimento obrigacional. A utilização da melhor diligência disponível e a prova da inexistência de negligência, imperícia ou imprudência por parte do contratado, desqualifica o inadimplemento obrigacional; pois, adimplir uma obrigação de meio é realizá-la com a dedicação que se espera do(a) profissional, e não necessariamente, conseguir êxito na tarefa. 
Ponderam Rainer Grigolo de Oliveira Alves e Jussara de Azambuja Loch (2012, p. 399), valendo-se do Direito Comparado em referência ao jurista francês François Chabas, igualmente defensor da obrigação de meio, afirmam que nem mesmo a ausência de consentimento ou deficiência na informação, possuem o condão de alterar a natureza jurídica da obrigação: "Nem nessa circunstância o médico deve ser responsabilizado por obrigação de resultado, mas sim à responsabilização por descumprimento culposo da obrigação de meio"

Assim, Nestor José Forster sintetiza o exposto:

\begin{abstract}
Evidentemente que o resultado procurado é a cura. Todavia, tal não poderá jamais ser exigido do médico, pois a ciência médica é, por definição, uma ciência incompleta, que a cada dia desbrava novas fronteiras, defrontando-se com enfermidades até então desconhecidas, talvez na mesma medida em que vai descobrindo os meios de curar muitas delas. Numa visão radical da questão, exigir do médico obrigação de resultado seria o mesmo que exigir dele onipotência divina, em que ele atuasse como senhor supremo da vida e da morte. Como, infelizmente, os seres humanos continuam a morrer, e isso ocorre também com os médicos, é evidente que a cura nem sempre é possível. Logo, tal resultado não poderia ser exigido de nenhum ser humano, nem mesmo do médico. (FORSTER, 1997, p. 408).
\end{abstract}

Consagrando o entendimento de liberdade individual, com fulcro na autonomia privada, não há espaço para a natureza jurídica da relação médico/paciente ser diferente de obrigação de meio; ressalvado o expresso compromisso do esculápio com o resultado sem margem para presunção deste. Porquanto, as condições pessoais do paciente possam ser desfavoráveis, aliás, não há garantias para o total êxito.

Exaltando o caráter interdisciplinar, próprio do Direito, é ventilado esclarecimentos ofertados pela Medicina, a fim de fornecer uma compreensão mais sofisticada acerca do tema. É imprescindível a distinção entre causa e fator, aquela definida como determinante da existência, condição necessária, sem a qual o fenômeno não ocorreria, inexistindo fonte de produção o fenômeno não acontecerá. $\mathrm{O}$ fator, embora não o produza, compete para sua maior ou menor incidência, sendo uma circunstância. Presentes, as causas endógenas, por si, ensejam o resultado adverso na cirurgia plástica.

Trata-se de entender os seres humanos como humanos que são (somos), assim, qualquer intervenção cirúrgica não se condiciona a "perfeição", esta pertencente ao plano onírico. Não obstante, o resultado esperado possa ocorrer, entretanto, dependente da mesma álea das demais cirurgias, é a conclusão alcançada por Juarez Moraes Avelar, a saber: 
Conclui-se, portanto, que a cirurgia plástica está exposta aos mesmos espinhos e dificuldades, como as demais áreas médicas. Assim sendo, não se pode, à luz da ciência, pretender exigir que os resultados obtidos pela cirurgia plástica sejam superiores aqueles propiciados por qualquer outra especialidade.

Os médicos (cirurgião plástico ou de outras especialidades) não podem assumir compromisso de êxito ou cura, senão emprego de técnicas consagradas ou comprovadas para alcançarem o melhor resultado possível em seus procedimentos [...]. (AVELAR, 2000, p. 133).

Em algumas situações, os aspectos científicos, cognitivos e técnicos, atribuídos ao médico, são insuficientes para sobrepujarem as causas genéticas, físicas, composição química, biológicas etc., que cada paciente traz consigo em sua "bagagem genética irrepetível", bastando ao(a) profissional valer-se de seus conhecimentos e prudência na fase pré-operatória e o indispensável acompanhamento pós-operatório.

Ao considerar toda cirurgia plástica estética obrigação de resultado, ignora-se as condições endógenas de cada paciente (químico-biológicas, caracteres hereditários, situação psíquica, predisposições, estrutura tecidual e orgânica etc.). Tais condições ultrapassam o controle médico, no qual toda perícia e prudência são insuficientes para obstar as sequelas que poderão ocorrer, pois o cirurgião não possui o "dom da cura ou embelezamento".

Oportuno frisar que por tal consideração, inexiste cirurgia embelezadora, não sendo prudente ao médico vincular-se ao resultado, diante da diversidade de respostas do organismo humano. No mesmo sentido, Juarez Avelar, assevera:

Os cirurgiões plásticos, bem como os demais especialistas enfrentaram e enfrentam as nuances individuais de cada ser humano, na busca constante da reparação do corpo [...]. Portanto, cientificamente e profissionalmente, é correto afirmar que a cirurgia plástica é obrigação de meio e não de resultado [...]. (AVELAR, 2000, p. 104).

O insucesso é caracterizado como risco inerente à atividade médica, ocorrendo situações em que não são contempladas pelo repertório da obrigação finalista. É essencial o direito a informação clara e precisa, consubstanciada a, também essencial, autonomia privada.

As próprias condições do paciente podem favorecer ao insucesso, devendo o cirurgião plástico adequar-se às particularidades do paciente. Com isso, objetiva-se compreender o Direito em sintonia com a realidade, distanciando-se da corrente majoritária que, comodamente, considera, de forma cabal, toda cirurgia plástica estética como obrigação de resultado. 
A turbulência afetiva, caracterizada principalmente pela dificuldade ou incapacidade de harmonizar conflitos internos, pode contribuir para o resultado adverso não apenas nas cirurgias plásticas, mas no tratamento médico em geral. As necessidades psicobiológicas não se encontram apartadas das sociais, assim, as disfunções psíquicas podem interferir negativamente no funcionamento do corpo, possibilitando à evolução de patologias, principalmente posterior ao do ato cirúrgico. Existe íntima relação entre psíquico e orgânico.

Clássico exemplo das condições pessoais são as chamadas queloides, que ainda hoje permanecem como incógnitas para a Medicina. De fato, as cicatrizes são inerentes a todo ato operatório, em maior ou menor evidência, mas sempre presentes. Existem pessoas que podem apresentá-las em determinada região do corpo e não em outras, da mesma forma, a involução espontânea do processo anômalo cicatrical.

Novamente recorre-se à definição apresentada por Avelar:

Vale relembrar que a formação de quelóide é um bom exemplo de má cicatrização causado por fatores intrínsecos. Denomina-se quelóide a uma tumação elevada, dura, de superfície lisa, com bordas irregulares, que se formam em cicatrizes e pode provocar doenças. Trata-se de uma cicatrização anômala (anormal) produzida pelo desenvolvimento exagerado do tecido cicatrical, que pode ocorrer em cicatrizes cirúrgicas ou causadas por acidentes ou queimaduras. Há um componente racial, como o fator intrínseco, de grande significado, pois a raça negra e amarela são as mais suscetíveis de apresentação de queloides. (AVELAR, 2000, p. 344).

Outro exemplo é a morfologia humana que é, por sua própria natureza, assimétrica; portanto, a exigência de alcançar rigorosa simetria entre partes do corpo, como condição de adimplemento contratual, encontra-se desarrazoada, infiel à realidade. A vida e a saúde humana não são ditadas por conceitos matemáticos, como pretendem os que preconizam a obrigação de resultado nas cirurgias plásticas.

Avelar (2000) afirma que as intercorrências podem ocorrer em fases distintas do ato cirúrgico: pré e pós-operatório (inflamações, infecções, reações alérgicas, cicatrizações etc.), revestidas sempre de imprevisibilidade em detalhes técnicos (hemorragias, lesões, variações de estruturas anatômicas, hematomas etc.) e, assim as define:

Como qualquer outra área cirúrgica, a Cirurgia Plástica é passível de falibilidade, porque se trata de uma Ciência/Arte especulativa, sujeita a várias circunstâncias, que podem ser denominadas de intercorrência, complicações ou mesmo de acidentes. (AVELAR, 2000, p. 349). 
Mesmo filiando-se a corrente oposta, Rui Stoco realiza importante manifestação acerca do erro médico escusável, que possui o condão de ilidir a responsabilização civil, dignas de transcrição:

Ocorre "erro profissional" quando a conduta médica é correta, mas a técnica empregada é incorreta. Significa que o médico aplica corretamente uma técnica ruim para aquele caso. [...]

A primeira hipótese ("erro profissional") contém o chamado "erro escusável", ou seja, justificável quando se cuida de técnica conhecida, usual e aceita. (STOCO, 2004, p. 532).

O citado autor, a fim de justificar seu posicionamento, embora conhecedor da corrente contrária, insere as citadas "intercorrências e episódios que atuam como elidentes de sua responsabilidade" (STOCO, 2004, p. 543), não desnaturando a obrigação de resultado, segundo o autor, "o guardião da vida" (médico), "Dele se exige correção, dedicação e até mesmo perfeição [...]”. (STOCO, 2004, p. 532).

Vênia concessa, acredita-se que diante dos argumentos expostos, a classificação como obrigação de resultado não se demonstra adequada, posto que lhe falta a mais elementar das características: a certeza na consecução do resultado.

Em suma, diante das condições pessoais (causas endógenas: químico-biológicas, caracteres hereditários, psicossomáticos, predisposições, morfologia assimétrica, estrutura tecidual e orgânica, intercorrências etc.), com respaldo na Medicina e com as considerações que conduziram os Conselhos (Federal e Regional) de Medicina, classificase cirurgia plástica como "obrigação de meio e não de fim ou resultado".

Toda cirurgia plástica, independente da subespécie, sujeita-se a mesma imprecisão das demais cirurgias, logo, deverão ser consideradas obrigação de meio. Outra conclusão é não é possível, senão, por apego ao hábito em classificar como obrigação de resultado, uma vez que, os argumentos apresentados, encontram guarida doutrinária e jurisprudencial.

Com o fito de aduzir que não se trata de voz destoante do todo, reúne-se alguns acórdãos, nos quais as razões de decidir são demonstradas, sinalizando uma guinada nas decisões judiciais. Assim, temos o voto proferido pelo Ministro do Superior Tribunal de Justiça - STJ, Carlos Alberto Menezes Direito, de compreensão ímpar, acerca da questão:

É chegado, agora, um tempo de necessária reflexão para reconhecer que os pacientes têm obrigações e os médicos também têm direitos, tudo para permitir um equilíbrio imperativo para a administração da justiça, ainda mais nesse trânsito da humanidade com novas descobertas da ciência médica. (BRASIL, 1996, p. 09). 
Assevera que: "Anote-se, nesse passo, que a literatura médica, no âmbito da cirurgia plástica, indica, com claridade, que não é possível alcançar $100 \%$ de êxito.” (BRASIL, 1996, p. 12). Divergindo apenas do posicionamento apresentado no tocante à promessa, segue afirmando:

Todavia, estes dois pontos, o compromisso com determinado resultado e a ausência e patologia, não servem para desqualificar a unidade científica do ato cirúrgico que, como vista supra, tem a mesma natureza e depende da mesma álea, não importando a subespecialidade. (BRASIL, 1996, p. 14).

\section{Enveredando para a conclusão de seu voto, clarifica:}

Enfim, há uma variedade enorme de circunstâncias que não devem ser vinculadas a um padrão imposto pela jurisprudência sob a configuração jurídica da cirurgia estética como obrigação de resultado, que pode levar, ademais, a absurdos como o conceito de aceitação do resultado diante de determinado detalhe, assim, por exemplo, o exato tamanho da mama, ou sua angularidade específica ou do nariz, ou ainda, o tamanho exato da cicatriz em uma cirurgia para eliminar a flacidez abdominal ou, até mesmo, um contrato de garantia para a resistência das mamas ou do enrijecimento do abdômen por certo tempo.

Por outro lado, não é possível estabelecer, talqualmente em direito não no é, um padrão de resultado uniforme em todos os pacientes, mesmo em se tratando de cirurgia em subespecialidade diversas da estética, dependendo o resultado, sempre, de muitos fatores até mesmo o comportamento do paciente. O que o cirurgião contrata com seu paciente é a realização de um ato cirúrgico com a melhor técnica possível, prestando-lhe detalhadamente todas as informações sobre as consequências da cirurgia, as comuns e as raras, para que a decisão seja tomada com toda a consciência, cabendo ao médico, ainda, avaliar com o maior rigor possível as condições do paciente para submeter-se a uma cirurgia. O que se não pode admitir é a repetição de um standart jurisprudencial que está em desalinho, a meu juízo, com a realidade mais moderna dos avanços da ciência médica e ciência jurídica.

Finalmente, nesse patamar, é bom não se esquecer que não se pode presumir, como parece vem sendo admitido pela jurisprudência, que o cirurgião plástico tenha prometido maravilhas ou que não tenha prestado as informações devidas ao paciente, configurando o contrato de resultado certo e determinado. A só afirmação do paciente em uma inicial de ação indenizatória não é suficiente para acarretar a presunção de culpa do médico, invertendo-se o ônus da prova, como no presente caso. O paciente deve provar que tal ocorreu, que não recebeu informações competentes e amplas sobre a cirurgia. [...]

$\mathrm{O}$ dito contrato para melhorar a aparência física do paciente por meio da cirurgia não depende, exclusivamente, da perícia ou diligência do cirurgião, mas, de fatores idênticos aos de qualquer outra cirurgia, devendo a responsabilidade do profissional ser apurada como prescreve o Código, mediante verificação de culpa. (BRASIL, 1996, p. 15-16, grifo no original).

Tamanha é a contundência do voto proferido pelo Ministro Menezes que nos dizeres do Ministro Eduardo Ribeiro observamos: "Revejo a posição doutrinária que anteriormente assumi. Do ponto de vista das consequências processuais [...]. A obrigação dos médicos em geral e do cirurgião em particular é de meio não de resultado". (BRASIL, 
1996, p. 25). Porém, prevalecem, acertadamente, os direitos do consumidor frente à legislação pertinente, art. $6^{\circ}$, VIII, CDC.

É de salutar que nem todos(as) os(as) magistrados(as) possuem tais esclarecimentos e conhecem a questão de modo a considerar a cirurgia plástica estética, obrigação de meio, juízo mais equânime, porém, os(as) que o fazem, aproximam o Direito da realidade fática. Igualmente merecedores de transcrição são os itens 05-06 da emenda do acórdão, in verbis:

5- A doutrina moderna não faz distinção entre a cirurgia estética e reparadora, atribuindo, por conseguinte, sempre ao cirurgião a obrigação de meio, pois, embora tenha prometido determinado resultado, não se pode imaginar que o procedimento ficará indene de fatos imprevisíveis, tais como reações que, porventura, possam advir ao organismo pelo ato cirúrgico.

6- Eventual intercorrência de fatores e reações estranhos à cirurgia configuram causas autônomas de rompimento do nexo etiológico, eximindo, em contrapartida, o profissional da responsabilidade pelos danos que refogem à conduta adotada. (MINAS GERAIS, 2008, p. 01).

Desenvolvendo os argumentos que lhe servem de fundamento, acerca do reconhecimento da obrigação de meio, atinente ao citado item 05 , segue expressando:

\begin{abstract}
Antes de prosseguir na análise da culpa atribuída ao réu, necessário diferenciar os diversos tipos de intervenção médica que, de acordo com o propósito a que se destinam, podem configurar obrigação de meio ou de resultado.

Modernamente há o entendimento, tanto na doutrina quanto na jurisprudência, de que as atividades médicas são obrigações de meio, mesmo aquelas inseridas no âmbito da cirurgia plástica.

O Ministro Ruy Rosado Aguiar Júnior, em excelente artigo publicado na Revista dos Tribunais, volume 718 , destaca que a doutrina moderna não faz distinção entre a cirurgia estética e reparadora, atribuindo, por conseguinte, sempre ao cirurgião a obrigação de meio, pois, embora tenha prometido determinado resultado, não se pode imaginar que o procedimento ficará indene de fatos imprevisíveis, tais como reações que, porventura, possam advir ao organismo pelo ato cirúrgico. Esclarece de maneira expressa que:

"Pode acontecer que algum cirurgião plástico, ou muitos deles assegurem a obtenção de um certo resultado, mas isso não define a natureza da obrigação, não altera a sua categoria jurídica, que continua sendo sempre a obrigação de prestar um serviço que traz consigo o risco" [...]. (MINAS GERAIS, 2008, p. 08).
\end{abstract}

Novamente demonstra que o Direito é móbil, aberto a interpretações cujo entendimento filiava-se a corrente de resultado e, atualmente (acertadamente), após debruçar-se sobre o tema na forma de um interdisciplinar "encontro com médicos", retifica seu "posicionamento acerca do tema":

AÇÃO ORDINÁRIA. CIRURGIA ESTÉTICA. OBRIGAÇÃO DE RESULTADO. DEVER DE INFORMAÇÃO. NÃO COMPROVAÇÃO. INVERSÃO DO ÔNUS DA PROVA. RESPONSABILIDADE SUBJETIVA. PRESUNÇÃO DE CULPA. A obrigação do médico na cirurgia plástica é de meio. Primeiro, porque conceito de "resultado" é subjetivo. Segundo, porque este não depende exclusivamente da vontade e habilidade técnica do médico, mas de reações do organismo humano que são, muitas vezes, imprevisíveis. A responsabilidade do médico é subjetiva, mas com a inversão do ônus da prova, 
devendo aquele demonstrar que adotou o procedimento correto. No caso, este restou comprovado, não havendo que se falar, portanto, em responsabilização. (MINAS GERAIS, 2009).

No caso sub judice, quanto à questão do dever de informar "Ademais, vejo que a paciente não informou aos médicos ser portadora de alergia, o que, sem sobra de dúvidas, poderia ter mudado o rumo dos acontecimentos”. (MINAS GERAIS, 2009, p. 05), torna-se patente que a informação exerce dupla função.

Com precisão, expõe os fundamentos da decisão:

Acreditava antes que a responsabilidade do médico na cirurgia plástica era de resultado, mas vislumbro que esse posicionamento é por demais injusto.

Primeiro, porque o conceito de "resultado" na cirurgia plástica é extremamente subjetivo. Às vezes, o resultado pode ter sido alcançado para o cirurgião, e não para o paciente.

Segundo, me afigura nem sempre possível alcançar o resultado pretendido, por não depender exclusivamente da vontade e habilidade técnica do médico, mas de reações do organismo humano que são, muitas vezes, imprevisíveis. (MINAS GERAIS, 2009, p. 06).

Sintetizando todo o exposto, exige-se o reconhecimento da obrigação do cirurgião plástico, independente da espécie do procedimento (reparador ou estético), como obrigação de meio, uma vez que balizamento doutrinário e jurisprudencial há para tanto; pois, inexiste vedação legal, contrariedade a entendimento sumulado ou que o resultado integre expressamente a avença (promessa), é a conclusão que se pretende construir.

\section{Dano, Responsabilidade Civil Médica e Código de Defesa do Consumidor}

Desde as primícias da humanidade, a reparação dos prejuízos é dotada de relevância, surgindo à responsabilidade civil; mais precisamente a responsabilidade civil médica encontrava previsão no primitivo código de Hamurabi ${ }^{16}$. O transcurso histórico aduz que o Direito, enquanto expressão divina somente os sacerdotes e nobres obtiveram acesso, enquanto razão apenas os sábios e filósofos. No paradigma do Estado de Democrático de Direito, o Direito deverá ser construído em conjunto de forma dialógica, viabilizando a democracia.

Da cirurgia plástica, fatidicamente poderão ocorrer algumas formas de dano, afetando diversos bens jurídicos tutelados. O entendimento do STJ, editado na Súmula 37, define que: "São cumuláveis as indenizações por dano material e moral oriundos do

\footnotetext{
${ }^{16} 218$ - Se um médico trata alguém de uma grave ferida com a lanceta de bronze e o mata ou lhe abre uma incisão com a lanceta de bronze e o olho fica perdido, se lhe deverão cortar as mãos.
} 
mesmo fato", pois, se compreende "indenizar" por danos diversos, embora originados da mesma fonte.

Os danos diferem-se quanto a sua natureza, entre patrimonial e extrapatrimonial, aqueles abrangidos pelos danos materiais e o lucro cessante (perdas e danos), e o dano moral e estético, ambos independentes, como forma de dano extrapatrimoniais. Geralmente, os danos decorrentes da cirurgia plástica são pluriofensivos, daí a necessidade de cumular indenização para os danos patrimoniais, retornando ao status quo ante, e a reparação visando mitigar o sofrimento extrapatrimonial.

A teoria clássica adota como elementos constitutivos da responsabilidade civil: conduta, culpa, dano e nexo de causalidade. Além destes elementos, requer a ausência de causas excludentes de responsabilidade. O elemento culpa subdivide-se ainda em imprudência, imperícia e negligência, que por sua vez também repercutem na esfera civil, aquela estando intimamente ligada à falta de cuidados indispensáveis à prática do ato cirúrgico, verdadeira falta de cuidado, prudência etc.

Imperícia configura-se pela inabilidade sob o prisma técnico, não-perito, ausência de habilidade, relacionada à falta de especialização para desenvolver a cirurgia plástica. Há distinção doutrinária quanto ao grau de culpa, podendo ser grave, leve ou levíssima. Grave é a culpa que se distancia em muito do óbvio, transgredindo os cuidados mais elementares; em sua modalidade leve é a desatenção à diligência ordinária, simples zelo mediano. Por fim, a culpa levíssima, na qual exige um descumprimento a uma atenção exacerbada, extremada.

Nexo causal é o liame entre a conduta médica e o dano provocado pela mesma, importante frisar que inexistindo o vínculo entre a conduta (positiva ou negativa) e o dano resultante, não há falar-se em responsabilização. Urge ressaltar que o nexo de causalidade se restringe exatamente aos fatos e a conduta médica ligando-os diretamente, corolário lógico, logo, não se indeniza mera expectativa, sonhos desfeitos etc. De modo sumário, são estes os elementos da responsabilidade civil.

Atinente a reparação dos danos, viceja discussão doutrinária acerca da aplicabilidade do CDC nas relações médico/paciente, visto que o Código de Ética Médica estabelece, em seus fundamentos e no tocante a remuneração, o afastamento da atividade médica ${ }^{17}$.

\footnotetext{
${ }^{17}$ Capítulo I - PRINCÍPIOS FUNDAMENTAIS [...]
}

IX - A Medicina não pode, em nenhuma circunstância ou forma, ser exercida como comércio. 
Afora esta, sustenta-se a incidência do estatuto consumerista ilidindo a corrente contrária, pela exegese de seu art. $2^{\mathrm{o}}$ : “Consumidor é toda pessoa física ou jurídica que adquire ou utiliza produto ou serviço como destinatário final" (BRASIL, 1990), não permitindo conclusão diversa.

Consoante com o CDC, que agasalha como regra a responsabilidade objetiva do fornecedor pelo "fato do serviço", ou seja, na ocorrência de dano, não se analisa culpa, pois o ponto de relevo está na conduta, dano e nexo causal.

A exceção será a responsabilidade civil subjetiva ${ }^{18}$, única previsão de tal instituto no referido Diploma Legal, não sendo extensiva a todo prestador de serviços, apenas à pessoa natural do profissional liberal. Ocorrendo acidente de consumo (lesão a direitos personalíssimos, vida, saúde, incolumidade etc.), deve-se perquirir acerca do elemento subjetivo culpa.

A vulnerabilidade é uma característica geral dos consumidores como um todo, logo, incide nas relações os direitos do consumidor ${ }^{19}$ e demais disposições do estatuto pertinente. Tem-se por oportuno, que na responsabilidade civil médica, deve-se fundar em culpa comprovada, não podendo, portanto, derivar-se de presunção, ainda que seja iuris tantum. Assim a obrigação de resultado, embasada na responsabilidade contratual, cujo fim colimado integra a satisfação da contraprestação médica, não se encontra alinhada ao preconizado na regra estatuída pelo CDC (responsabilidade subjetiva).

Vale ressaltar que a colaboração recíproca é pressuposto contratual, no qual o contrato de prestação de serviço médico aperfeiçoa-se com o consenso das partes (contratos negociáveis), antônimo dos contratos de adesão. Em regra, são contratos intuitu personae, consequência da natural confiança dos serviços prestados pelos profissionais liberais.

XIX - O médico se responsabilizará, em caráter pessoal e nunca presumido, pelos seus atos profissionais, resultantes de relação particular de confiança e executados com diligência, competência e prudência.

XX - A natureza personalíssima da atuação profissional do médico não caracteriza relação de consumo.

Capítulo VIII - REMUNERAÇÃO PROFISSIONAL

É vedado ao médico:

Art. 58. O exercício mercantilista da Medicina.

$18 \mathrm{CDC}$, art. $14, \S 4^{\circ}$. A responsabilidade pessoal dos profissionais liberais será apurada mediante a verificação de culpa.

${ }^{19} \mathrm{CDC}$, art. $6^{\circ}$. São direitos básicos do consumidor:

VIII - a facilitação da defesa de seus direitos, inclusive com a inversão do ônus da prova, a seu favor, no processo civil, quando, a critério do juiz, for verossímil a alegação ou quando for ele hipossuficiente, segundo as regras ordinárias de experiências; 
$\mathrm{Na}$ atividade de cooperação (ausência de conflito de interesses) médico/paciente deve-se aplicar o instituto da responsabilidade subjetiva. Não há falar-se em indenização pela não consecução do resultado, salvo quando o esculápio expressamente comprometerse ao mesmo. Perfaz autêntica indenização/reparação dos danos admitindo-se, também, a restituição dos honorários advocatícios do autor, em atenção à plena reparação.

Admite-se, outrossim, para afastar a responsabilidade civil pela comprovação, via perícia médica direta ${ }^{20}$ ou indireta $^{21}$, quando o dano alegado inexiste ou ocorreu por culpa exclusivamente imputada ao consumidor ou a terceiro, consoante o art. 14 , § $3^{\circ}$, I e $\mathrm{II}^{22}$, CDC. Assim, as fontes de responsabilidade civil provêm de violação de lei preexistente, ou de convenção entre as partes (extracontratual e contratual), a qual resulta na obrigação, do causador do dano, em indenizar o lesionado.

Em âmbito processual, na fase cognitiva, as partes expõem os fatos para justificar sua pretensão ou contestação; contudo, a veracidade dos fatos revela-se mediante produção probatória trazida aos autos do processo. Ao analisar a responsabilidade civil e seus reflexos no ônus probatório, desde que não expressamente prometido o resultado, este não integra o conjunto fático probatório (o resultado é um evento aleatório); a censura decorrerá da infração no dever de prudência na conduta médica, desde que comprovada a culpa.

Do médico generalista exige-se a diligência necessária, pressuposto para a relação médico/paciente, e do especialista (cirurgião plástico) exige-se maior perícia e prudência. A essência de sua profissão, que combina denso conhecimento teórico com um aprendizado empírico que não se esgota. A responsabilização de ambos os profissionais deverá ser a regra anteriormente relatada (subjetiva). Registra-se que o médico é responsável pela equipe, salvo o médico anestesista, que responde de forma pessoal.

\footnotetext{
${ }^{20}$ Conforme sítio eletrônico, Portal Médico: "Exame clínico do periciado, na realização de eventuais exames complementares, bem como na análise dos documentos e das informações relativas ao seu histórico médico, ocupacional e familiar".

${ }^{21}$ Ainda, segundo o mesmo sítio eletrônico: "Realizada com base exclusivamente nos documentos médicos do falecido acostados aos autos, bem como nas informações relativas ao seu histórico familiar e ocupacional".

${ }^{22}$ CDC, art. 14. O fornecedor de serviços responde, independentemente da existência de culpa, pela reparação dos danos causados aos consumidores por defeitos relativos à prestação dos serviços, bem como por informações insuficientes ou inadequadas sobre sua fruição e riscos.

[...]

$\S 3^{\circ} \mathrm{O}$ fornecedor de serviços só não será responsabilizado quando provar:

I - que, tendo prestado o serviço, o defeito inexiste;

II - a culpa exclusiva do consumidor ou de terceiro.
} 
Tem-se como um contrato de prestação de serviços típico, de natureza mista, cuja natureza jurídica é sui generis obrigação contratual e extracontratual, no qual o paciente possui o inarredável direito a informação clara e precisa, de fácil entendimento, adequado à boa-fé objetiva.

Ao se aplicar a responsabilidade subjetiva, na ocorrência de dano, o médico será responsabilizado baseado na teoria da causalidade necessária, responsabilidade subjetiva; incumbindo-lhe demonstrar a diligência adequada e utilização das técnicas disponíveis para afastar a possibilidade de sofrer repressões civis não pela presunção da culpa, mas, por tratar-se de direitos básicos do consumidor.

Posto que o CDC incide sobre os contratos de cirurgia plástica é mister salientar, sem temor de redundância, que se faz necessário assessoramento de profissional, devidamente habilitado(a), na área do Direito, para as orientações pertinentes também na elaboração do instrumento contratual.

\section{Reflexos na responsabilidade civil referente ao onus probandi}

A complexidade do tema exige do(a) julgador(a) uma percepção atenta às variáveis e aos interesses em questão. Necessário, portanto, interpretar o Ordenamento Jurídico de forma sistêmica, pela leitura teleológica do Direito, a partir da visão multidisciplinar, observando o valor fundamental ao elemento saúde. Assim, os contornos da responsabilização decorrente do exercício da cirurgia plástica, a ser imputada ao médico na ocorrência de danos, devem fundar-se em culpa comprovada do profissional.

A função da responsabilidade civil, de forma abreviada, é reparar (ou uma tentativa), reestabelecendo o status quo ante; ou seja, a responsabilidade civil destina-se a nivelar o lesado próximo da situação em que estaria, não fosse o dano.

A responsabilidade pode advir de um descumprimento contratual ou decorrente de um liame legal. Na primeira hipótese refere-se à responsabilidade contratual disciplinada pelo art. $389^{23}$ do Código Civil de 2002, na seguinte, ocorre a responsabilidade extracontratual ou aquiliana, com fulcro na cláusula aberta de responsabilidade civil, disposta no art. $927^{24}$ do mesmo Diploma Legal.

\footnotetext{
${ }^{23} \mathrm{CC}$, art. 389. Não cumprida a obrigação, responde o devedor por perdas e danos, mais juros e atualização monetária segundo índices oficiais regularmente estabelecidos, e honorários de advogado.

${ }^{24}$ CC, art. 927. Aquele que, por ato ilícito (arts. 186 e 187), causar dano a outrem, fica obrigado a repará-lo.
} 
A responsabilidade contratual (negocial), consiste na violação de um dever estabelecido anteriormente em contrato. No caso do cirurgião plástico é a fase que antecede a relação negocial (puntuação) que será analisada a relação obrigacional, consubstanciada no acordo de vontades, se de meio ou de resultado.

Em havendo dano, origina-se o dever sucessivo de reparação, e essa responsabilização será objetiva ou subjetiva? Com base no que foi exposto, entende-se que a responsabilidade do cirurgião plástico deve ser subjetiva, ou seja, é necessário demonstrar o elemento culpa. Esta é a perspectiva acolhida pelo art. 14, § $4^{\text {o25 }}$, CDC. Ademais, o Código de Ética Médica possuí aplicação subsidiária, considerado pelo julgador na aferição da culpa, pois na responsabilidade médica (profissional liberal) não se admite presumir culpa, deve-se comprovar mediante análise exaustiva dos métodos adotados pelo profissional no ato cirúrgico.

Ainda no que tange à comprovação, cumpre, ressaltar que em regra, cabe ao autor(a) ou sucessor(a) provar as alegações que constituem seu direito. Entretanto, com a incidência da Legislação Consumerista, CDC, é possível a inversão do ônus da prova, quando da verossimilhança das alegações do consumidor.

As obrigações médicas são decompostas em: aconselhamento, cuidados de assistência e abstenção de abuso do direito. Acrescenta-se o importante dever de informação, que impõe ao médico a exposição ao paciente, de maneira clara e precisa, dos efeitos colaterais e os riscos inerentes ao procedimento. Além da delimitação de direitos e obrigações, importa a atenção à natureza da relação médico/paciente, quando da análise do caso concreto, observando a fase de puntuação. Impõem-se, portanto, a existência de culpa.

$\mathrm{Na}$ obrigação de meio, em regra, o paciente deverá comprovar a conduta ilícita do médico, isto é, que o devedor não atuou com a diligência adequada. Na de resultado presume-se que a não obtenção decorre da atuação culposa do médico. Entretanto, mesmo nas obrigações de meio haverá espaço para condutas culposas que ensejem a obrigação de indenizar, não havendo, portanto, prejuízo para a reparação do dano suportado pelo(a) paciente.

É mister observar que a demonstração da culpa do médico, a princípio, seria obrigação do paciente, contudo, se o médico prometer o resultado, estará vinculado a este, por isso, na presença de vício do serviço (não alcançar o resultado), ocorre inadimplemento

$25 \mathrm{CDC}$, art. 14, $\S 4^{\circ}$. A responsabilidade pessoal dos profissionais liberais será apurada mediante a verificação de culpa. 
contratual. Em aspectos processuais, incumbe ao(a) advogado(a) demonstrar no juízo singular toda matéria fática, apta a sustentar a obrigação de meio; posto que, em havendo sentença desfavorável, em grau de recurso, não há como falar-se em dilação probatória.

Aflora o mito do resultado nas cirurgias plásticas, na jurisprudência majoritária, com parca e insuficiente fundamentação. Ao enfrentar a questão, parte da premissa do resultado, alegando a ausência de patologia e o animus do contratante, na quase totalidade das demandas apreciadas.

Redundando em uma perspectiva meramente dogmática. Pelos ensinamentos de Manuel Atienza (2003, p. 22), perfaz-se em um “determinismo metodológico", no qual se desconhece os princípios metodológicos de interpretação e explicação que conduzem a classificação da cirurgia estética como obrigação de resultado.

Ademais, na maioria dos casos concretos analisados pelo Judiciário, o tema apreciado por este artigo, não é enfrentado. Simplesmente, como já foi dito, iniciam com a premissa do resultado e ao depararem-se com o erro médico inescusável, ensejador de reparação civil, concluem, sem maiores reflexões, a natureza jurídica da obrigação por parte do médico.

\section{Considerações finais}

Ante as exposições demostradas no decurso do artigo, alguns apontamentos ainda vêm a calhar, que serão (re)afirmados como elementos que balizaram o escrito e permitem considerar que, após devassar a natureza jurídica da responsabilidade civil médica, alcança-se à conclusão que em regra a atividade do médico-cirurgião plástico deve ser classificada, sob o enfoque jurídico, como obrigação de meio. Esta é a premissa que norteou todo o artigo e também a conclusão alcançada.

Da cirurgia plástica poderão advir algumas formas de dano e, geralmente, mais de uma por se tratar de evento pluriofensivo. O paciente está sujeito a danos materiais (de ordem econômica ou patrimonial), lucro cessante (quantia que, razoavelmente, deixou de auferir), danos morais (de ordem extrapatrimoniais) e danos estéticos (alteração morfológica causando fealdade em seu aspecto corpóreo). Admite-se a tripla cumulação (material, moral e estético) de "indenização" em decorrência do mesmo fato.

Questão relevante é a promessa, expressa e inequívoca, que possuí o condão de alterar a obrigação médica, que em regra é considerada de meio, transmutando-a em 
obrigação de resultado; pois, quando o esculápio promete ao paciente resultado certo e determinado, estará a ele vinculado, uma vez que o estímulo do paciente deve corresponder ao próprio resultado específico pretendido.

Incumbe ao médico prudente evitar à promessa, pois, como já dito, esta altera a natureza jurídica da obrigação, bastando que o resultado não seja alcançado para que o paciente seja indenizado pelo inadimplemento contratual e eventuais danos, inclusive aos honorários advocatícios.

O Código de Defesa do Consumidor abarca as relações médico/paciente, pois o paciente é o destinatário final do serviço médico prestado, e o médico, fornecedor que desenvolve atividade de prestação de serviço remunerado. Sendo aplicáveis as disposições do CDC à relação contratual, remanesce que a responsabilidade subjetiva do médico, profissional liberal (art. 14, § $4^{\circ}, \mathrm{CDC}$ ), ou seja, passível de repressão civil apenas se obrar com culpa (imperícia, imprudência ou negligência).

Sempre presente o inarredável direito à informação do consumidor que adquire relevância especial na cirurgia plástica estética; pois cabe ao médico-cirurgião prestar aos pacientes; informações completas, precisas e inteligíveis, considerando que aquele é o detentor do conhecimento técnico de possíveis riscos e insucessos que envolvem o procedimento.

Salienta-se que as referidas informações, bem como o consentimento outorgado pelo paciente, devem constar, preferencialmente, no termo de consentimento elaborado com a orientação de advogado(a), delimitando os contornos do negócio jurídico.

A assunção de eventuais riscos, por parte do paciente, desincumbe o médico do dever de alcançar o resultado, mas não da responsabilidade civil por eventuais danos. Portanto, estas disposições não produzirão qualquer efeito na ordem jurídica; ou seja, serão consideradas nulas de pleno direito as cláusulas que exonerarem o médico da obrigação de indenizar.

Considera-se ponto fundamental para dissidiar da corrente majoritária, obrigação de resultado, ponderando que nem todo resultado inestético é sinônimo de erro médico. Posto que na especialidade cirurgia plástica, assim como nas demais áreas da Medicina, encontra-se exposta as imprevisíveis reações do organismo humano. Não há que se falar em obrigação de resultado como regra.

O resultado, cirurgicamente possível a ser alcançado, está limitado às condições endógenas que cada paciente traz consigo. Assim, os eventos classificados pela Medicina 
como intercorrências, queloides, causas psicossomáticas etc., quando devidamente comprovadas atuam como elidentes de responsabilidade, bem como o dano alegado inexistente, ou que ocorreu por culpa exclusivamente imputada ao consumidor ou a terceiro, consoante o art. $14, \S 3^{\circ}$, I e II, CDC, igualmente, obstando a indenização.

Somente o caso concreto, individualmente considerado, será capaz de considerar questões bioéticas fazendo-se um redimensionamento axiológico sobre o tema, concebendo que a ciência médica é imperfeita, decorrente das limitações do conhecimento científico e em constante aperfeiçoamento. Reafirma-se a desnecessidade de se analisar a relação exclusivamente sob o viés jurídico.

Toda cirurgia plástica, independente da subespécie (estética, reparadora ou reconstrutiva) está sujeita a mesma álea das demais cirurgias; portanto, deverão ser consideradas obrigação de meio. A própria morfologia humana é por natureza assimétrica, por conseguinte, a exigência de alcançar rigorosa simetria entre partes do corpo, como condição de adimplemento contratual da avença médica, encontra-se no mínimo desarrazoada, infiel à realidade. A vida e a saúde humana não são ditadas por conceitos exatos, como comodamente pretendem os que preconizam a obrigação de resultado.

De todo o exposto deflui-se que o resultado não deverá integrar a relação contratual, ressalvada a promessa expressa e inequívoca, na qual o médico-cirurgião plástico vincula-se ao seu alcance. Embora, aquele possa ser o motivo para o paciente, porém as limitações médicas (ciência) e biológicas (pessoais) são preponderantes ao animus dos contratantes, portanto, subjacente à realidade fática.

Ademais, a quase totalidade das análises realizadas pelo Judiciário, nos casos concretos, não enfrentam o tema apreciado por este artigo. Partem da premissa do resultado e ao se depararem com o erro médico inescusável, ensejando em reparação por parte do médico-cirurgião plástico e, precipitadamente, concluem que toda cirurgia plástica estética é obrigação de resultado.

Em síntese, ao conceber a atividade médica do cirurgião plástico como obrigação de meio, aproxima-se a realidade jurídica da realidade fática cirúrgica em consonância com a Dignidade da Pessoa Humana, simplesmente porque o médico não pode criar "beleza". Dessa forma, reconhece-se a necessidade de enfrentar e interpretar a questão numa outra tônica jurídica. 


\section{REFERÊNCIAS}

ALVES, Rainer Grigolo de Oliveira. LOCH, Jussara de Azambuja. Responsabilidade civil do cirurgião plástico em procedimentos estéticos: aspectos jurídicos e bioéticos. Revista bioét, Porto Alegre, n. 20. p. 397-403, 2012. Disponível em:

<http://revistabioetica.cfm.org.br/index.php/revista_bioetica/article/viewFile/758/811>. Acesso em: 10 jun. 2014.

ARRAES, Roberto Batista Montefusco. O dano estético: conceito e incidência à luz das novas perspectivas doutrinárias e jurisprudenciais. Revista de Direito Privado. São Paulo, v. 11, n. 44 , p. $106-136.14$ out. 2010.

ATIENZA, Manuel. As razões do direito: teorias da argumentação jurídica. 3. ed. Tradução de Maria Cristina Guimarães Cupertino. São Paulo: Landy, 2003.

AVELAR, Juarez Moraes. Cirurgia plástica: obrigação de meio e não obrigação de fim ou resultado. São Paulo: Hipócrates, 2000.

ÁVILA, Luiz Augusto de. Lógica jurídica: uma análise linguística das regras de predicação e intermediação de conceitos jurídicos. Belo Horizonte: Arraes, 2013.

BRASIL. Lei n. 8.078 de 11 de setembro de 1990. Dispõe sobre a Proteção do Consumidor e dá outras providências. Diário Oficial da União, Brasília, 12 de setembro de 1990.

BRASIL. Lei n. 10.406 de 10 de janeiro de 2002. Institui o Código Civil. Diário Oficial da União, Brasília, 11 de janeiro de 2002.

BRASIL. Superior Tribunal de Justiça. Recurso Especial 81.101/PR. Relator: Waldemar Zveiter - Terceira Turma. Diário de Justiça Eletrônico, Brasília,

05 nov. 2010. Disponível em: <http://www.stj.jus.br/SCON/> Acesso em: 25 fev. 2014.

BRASIL. Superior Tribunal de Justiça. Súmula 37. Diário de Justiça, Brasília, 17 mar. 1992. Disponível em:

<http://www.trtsp.jus.br/geral/tribunal2/Trib_Sup/STJ/SUM_STJ.html>. Acesso em: 16 jul. 2015.

CONSELHO FEDERAL DE MEDICINA. Código de ética médica: Resolução CFM n. 1.931, 17 de setembro de 2009. Brasília: Conselho Federal de Medicina, 2010. (versão de bolso).

CONSELHO FEDERAL DE MEDICINA. Resolução n. 1.621/2001. 2013. Disponível em: <http://www.portalmedico.org.br/resolucoes/cfm/2001/1621_2001.htm>. Acesso em: 18 maio 2013.

CONSELHO REGIONAL DE MEDICINA DO ESTADO DE SÃO PAULO. Resolução n. 81/1997. 2014. Disponível em: 
$<$ https://www.cremesp.org.br/library/modulos/legislacao/versao_impressao.php?id=3204\& versao=integra $>$. Acesso em: 04 jun. 2014.

DIAS, Maria Tereza Fonseca; GUSTIN, Miracy Barbosa de Sousa. (Re)pensando a pesquisa jurídica: teoria e prática. 4. ed. rev. e atual. Belo Horizonte: Del Rey, 2015.

FILHO, Sergio Cavalieri. Programa de responsabilidade civil. 9. ed. rev. atual. e ampl. São Paulo: Atlas, 2010.

FORSTER, Nestor José. Cirurgia plástica estética: obrigação de resultado ou obrigação de meios? Revista da AJURIS. Porto Alegre, n. 69 mar. 1997. p. 407-414. Disponível em: $<$ http://livepublish.iob.com.br/ntzajuris/lpext.dll/Infobase/4c800/4d5cd/4d618?f=templates $\& \mathrm{fn}=$ document-frame.htm\&2.0>. Acesso em: 10 jun. 2014.

GONÇALVES, Carlos Roberto. Direito civil brasileiro: responsabilidade civil. 7. ed. São Paulo: Saraiva, 2012. v. 4.

GONÇALVES, Carlos Roberto. Direito civil brasileiro: teoria geral das obrigações. 8. ed. São Paulo: Saraiva, 2011. v. 2.

GALUPPO, Marcelo Campos. Da ideia à defesa: monografias e teses jurídicas. Atual. Belo Horizonte: Mandamentos, 2003.

KANT, Immanuel. Fundamentação da metafísica dos costumes. Rio de Janeiro: Edições 70, 1991. (Textos filosóficos 70).

KELSEN, Hans. Teoria pura do direito. Tradução de João Baptista Machado. 8. ed. São Paulo: WMF Martins Fontes, 2009.

KLAUDAT, André Nilo. A obrigação da promessa em Hume. Kriterion: Revista de Filosofia. Belo Horizonte: UFMG, Faculdade de Filosofia e Ciências Humanas, v. 52, n. 124, dezembro 1947.

LIMA, Gislânia Ferreira de. O consentimento informado, o princípio da autonomia e a proteção jurídica na relação médico-paciente. Jus Navigandi, Teresina, Ano 19, n. 3906, 12 mar. 2014. Disponível em: <http://jus.com.br/artigos/26868>. Acesso em: 03 abr. 2014.

LOPEZ, Teresa Ancona. O dano estético: responsabilidade civil. 2. ed. rev. atual. e ampli. São Paulo: Revista dos Tribunais, 1999.

MARI, Hugo. A promessa como ato de fala: suas implicações no discurso 'político'.

Geraes Revista de Comunicação Social, FAFICH/UFMG, Belo Horizonte, jun. v. 1, p. 34-41, 1997.

MINAS GERAIS. Tribunal de Justiça. Apelação Cível 1.0024.04.192488-7/002. Relator: Francisco Kupidlowski. Belo Horizonte, 01 dez. 2008. Disponível em:

<http://www5.tjmg.jus.br/jurisprudencia/pesquisaNumeroCNJEspelhoAcordao.do?numero Registro $=1 \&$ totalLinhas $=1 \&$ linhasPorPagina $=10 \&$ numeroUnico $=1.0024 .04 .192488$ -

7\%2F002\&pesquisaNumeroCNJ=Pesquisar>. Acesso em: 10 jun. 2014. 
MINAS GERAIS. Tribunal de Justiça. Apelação Cível 1.0145.06.330041-5/001. Relator: Antônio Bispo. Belo Horizonte, 08 maio 2009. Disponível em:

<http://www5.tjmg.jus.br/jurisprudencia/pesquisaNumeroCNJEspelhoAcordao.do?numero Registro $=1 \&$ totalLinhas $=1 \&$ linhasPorPagina $=10 \&$ numeroUnico $=1.0145 .06 .330041$ 5\%2F001\&pesquisaNumeroCNJ=Pesquisar>. Acesso em: 27 fev. 2014.

MONTALVÃO, Alberto Siqueira. Erro médico: reparação do dano material, estético e moral. Doutrina, Legislação e Jurisprudência. São Paulo: Julex 1998. v. 1.

NADER, Paulo. Curso de direito civil: contratos. 2. ed. Rio de Janeiro: Forense, 2006. v. 3 .

NADER, Paulo. Curso de direito civil: responsabilidade civil. 3. ed. rev. e atual. Rio de Janeiro: Forense, 2010. v. 7.

ORGANIZAÇÃO MUNDIAL DA SAÚDE. Constituição da Organização Mundial da Saúde - OMS/WHO - 1946. Disponível em: 〈http://www.onuportugal.pt/"oms.doc〉. Acesso em: 14 jun. 2014.

PORTAL DO MÉDICO. Perícia direta indireta CFM. 2014. Disponível em: <http://www.portalmedico.org.br/notasdespachos/CFM/2013/25_2013.pdf>. Acesso em: 29 abr. 2014.

RIBEIRO, Renato Janine. Não há pior inimigo do conhecimento que a terra firme. Tempo Social: Revista de Sociologia da USP, São Paulo, n. 11, p. 189-195, maio 1999.

RIZZARDO, Arnaldo. Responsabilidade civil. 4. ed. rev. e atual. Rio de Janeiro: Forense, 2009.

STOCO, Rui. Tratado de responsabilidade civil. 6. ed. São Paulo: Revista dos Tribunais, 2004.

TSUKAMOTO, Fabiana. Reparação civil do dano estético nas cirurgias plásticas. 2004. 78f. Monografia (Conclusão de curso) - UNIFMU Centro Universitário. São Paulo.

Disponível em: 〈http://arquivo.fmu.br/prodisc/direito/ft.pdf〉. Acesso em: 05 jun. 2013.

UNIVERSIDADE FEDERAL DE CAMPINA GRANDE. Asclépio ou Esculápio. 2013. Disponível em:<http://www.dec.ufcg.edu.br/biografias/MGAsclep.html>. Acesso em: 10 out. 2013.

VALLE, Cristiano Almeida do. Dano moral doutrina modelos jurisprudência. Rio de Janeiro: AIDE, 1999.

VENOSA, Sílvio de Salvo. Direito civil: responsabilidade civil. 10. ed. São Paulo: Atlas, 2010. v. 4.

VIEIRA, Luzia Chaves. Responsabilidade civil médica e seguro: doutrina e jurisprudência. Belo Horizonte: Del Rey, 2001. 
WOLF, Naomi. O mito da beleza: como as imagens de beleza são usadas contra as mulheres. Tradução de Waldéa Barcellos. Rio de Janeiro: Rocco, 1992. 